\title{
The Effect of Omeprazole on the Pharmacokinetics of Piroxicam Profiles with High Performance Liquid Chromatography (HPLC) Method
}

\author{
Firdaus Fahdi, Herviani Sari, Sulasmi, Wahyudi \\ Department of Pharmaceutical, Faculty of Pharmacy, Institut Kesehatan Deli Husada Deli Tua, \\ Indonesia
}

\begin{abstract}
Piroxicam is an anti-inflammatory drug of the NSAID class that is commonly used as an analgesic and anthireumatic drug. Its use is often combined with gastric drugs, one of which is omeprazole, considering the side effects of piroxicam which can irritate the stomach. Piroxicam and omeprazole work on the same enzyme, CYP-450 so that it can affect the pharmacokinetic profile especially in the metabolic and excretion phases of piroxicam. This research is an experimental study using 3 male rabbits. Measurement of plasma levels of piroxicam drug is carried out using a High Performance's Liquid Chromatography (HPLC) tool. The validation method is used to determine LOD and LOQ values, accuracy, and precision tests. The results of data analysis using t-tables. The results showed the value of pharmacokinetic parameters in the absorption phase increased or there were differences but did not show any significant effect on each group. While the pharmacokinetic parameter values in the metabolic and excretion phases decreased and showed no differences between groups. The administration of omeprazole and piroxicam together and the administration of piroxicam which was given an hour earlier by omeprazole can inhibit the enzyme that stimulates the metabolism of piroxicam so that it affects the pharmacokinetic parameters in the absorption phase and also excretion but is not significant.
\end{abstract}

Keyword:Pharmacokinetics, Inhibition of Metabolic Enzymes, Piroxicam, Omeprazole

\begin{abstract}
Abstrak. Piroxicam adalah obat antiinflamasi golongan NSAID yang biasa digunakan sebagai obat analgesik dan antirematik. Penggunaannya sering dikombinasi dengan obat lambung salah satunya omeprazole mengingat efek samping dari piroxicam yaitu dapat mengiritasi lambung. Piroxicam dan omeprazole bekerja pada enzim yang sama yaitu CYP-450 sehingga dapat mempengaruhi profil farmakokinetika terutama pada fase metabolisme dan eksresi piroxicam.Tujuan penelitian ini untuk mengetahui pengaruh pemberian omeprazole terhadap profil farmakokinetika piroxicam terutama pada fase metabolisme dan eksresi. Penelitian ini adalah penelitian eksperimental menggunakan 3 ekor kelinci jantan. Pengukuran kadar obat piroxicam dalam plasma dilakukan dengan menggunakan alat Kromatografi Cair Kinerja Tinggi (KCKT). Dilakukan metode validasi yaitu penentuan nilai $L O D$ dan $L O Q$, uji akurasi dan uji presisi. Hasil analisis data menggunakan t tabel.Hasil penelitian menunjukkan nilai parameter farmakokinetika pada fase absorpsi mengalami peningkatan atau terdapat perbedaan namun tidak menunjukkan adanya pengaruh yang berarti pada masing-masing kelompok. Sementara nilai parameter farmakokinetika pada fase metabolisme dan eksresi mengalami penurunan dan menunjukkan adanya perbedaan antara kelompok tidak signifikan. Pemberian omeprazole
\end{abstract}

\footnotetext{
*Corresponding author at:Department of Pharmaceutical, Faculty of Pharmacy, Institut Kesehatan Deli Husada Deli Tua, Indonesia
}

E-mail address: daus2966@gmail.com 
dan piroxicam secara bersamaan dan pemberian piroxicam yang satu jam sebelumnya telah diberikan omeprazole dapat menginhibisi enzim pemetabolisme piroxicam sehingga mempengaruhi parameter farmakokinetika pada fase absorbs dan juga eksresi namun tidak signifikan.

Kata Kunci:Farmakokinetika, Inhibisi Enzim Pemetabolisme, Piroxicam, Omeprazole

Received 4 June 2020 | Revised 26 June 2020 | Accepted 28 July 2020.

\section{Introduction}

The use of drugs for more than one active substance (polypharmacy) in the treatment of disease is often found in a patient. The complexity of the drugs used allows drug interactions, where a substance influences drug activity, for example the effect of increasing or decreasing or producing new effects that are not produced by the drug itself. This interaction needs to be considered because it affects the body's response to treatment [1,2,3]. A drug interaction occurs when a patient's response to a drug is modified by food, nutritional supplements, formulation excipients, environmental factors, other drugs or disease. Interactions between drugs may be beneficial or harmful [4]. Drug interactions can provide changes to drug activity, either by increasing toxic effects or decreasing therapeutic effects [5].In addition, some drug interactions can also support each other's work or the opposite of drug interactions can result in the action of one drug inhibited by other drugs [6].

One mechanism of drug interactions that occur in the body is pharmacokinetic interactions that occur when one drug can affect the absorption, distribution and elimination (metabolism and excretion) of other drugs, so that the level of the affected drug will increase or decrease [2]. Interactions in metabolic processes are the most common cases, where about $50-60 \%$ of the drugs used in therapy can interact with each other on the same enzyme[7]. Piroxicam is a drug that has analgesic, antirheumatic and anti-inflammatory activity which is more or less the same as indomethacin, a relatively long work period with a dose of 10-20 mg daily. Piroxicam is well absorbed in the digestive tract, $99 \%$ of the drug is bound by plasma protein [8]. Piroxicam is often combined with gastrointestinal medication given the side effect of piroxicam is that it can irritate the stomach. And in this study, the stomach medicine used is omeprazole, which is one drug that is widely used in the community. This study was conducted with the aim of finding out whether or not there was an influence on the administration of omeprazole on the pharmacokinetic profile of piroxicam, especially in the metabolic phase and also in the excretion phase.

\section{Materials and Methods}

This research was an experimental research. The tools used in this study were a complete HPLC unit (Shimadzu), politube, beaker glass, vortex, waterbath, centrifuge, pumpkin, $\mathrm{pH}$ meter, PTFE membrane filter $0.5 \mu \mathrm{m}$, measuring cup, analytical balance (Boeco Germany ), volume 
pipettes, drop pipettes, gloves, syringes (Terumo), oral sonde, stopwatch, rabbit cages, masks, animal scales. The materials used in this research were standard piroxicam (PT. Brataco), piroxicam and omeprazole tablets, sodium CMC, aquabidest, methanol PA (E.Merck), TCA, heparin, distilled water.

\subsection{Preparation of Suspension}

The preparation of suspension carried out in this study was the manufacture of $0.5 \%$ Sodium CMC suspense using $2.5 \mathrm{~g} \mathrm{CMC} \mathrm{Na} \mathrm{sprinkled} \mathrm{evenly} \mathrm{into} \mathrm{a} \mathrm{mortar} \mathrm{containing} 100 \mathrm{ml}$ of hot distilled water. Allowed to stand for 30 minutes to obtain a transparent mass, then diluted with $500 \mathrm{~mL}$ of distilled water. Then preparation of suspension, piroxicam weighed as much as 10 mg gently crushed in a mortar, add $50 \mathrm{ml}$ of $0.5 \%$ CMC Na suspension homogenized, then transferred to a $100 \mathrm{ml}$ volumetric flask, then added $0.5 \% \mathrm{CMC} \mathrm{Na}$ until it was reached the mark limit. Preparation of Omepraole suspension, Omeprazole weighed as much as $20 \mathrm{mg}$ gently crushed in mortars, added $50 \mathrm{ml}$ of $0.5 \% \mathrm{CMC} \mathrm{Na}$ suspension homogenized then transferred into a $100 \mathrm{ml}$ volumetric flask, then added $0.5 \% \mathrm{CMC}$ Na to the marking limit [9].

\subsection{Tests on the pharmacokinetics profile}

The testing of pharmacokinetic profiles was carried out with 3 treatments. The first treatment was the treatment in experimental animals by administering piroxicam at a dose of 0.653 $\mathrm{mg} / \mathrm{kgbw}$ without omeprazole administration. The second treatment was the treatment in experimental animals by administering piroxicam at a dose of $0.606 \mathrm{mg} / \mathrm{kgbw}$ which 1 hour earlier was given omeprazole at a dose of $1.2 \mathrm{mg} / \mathrm{kgbw}$. The third treatment, namely the treatment of experimental animals by administering piroxicam at a dose of $0.7 \mathrm{mg} / \mathrm{kgbw}$ together with omeprazole at a dose of $1.4 \mathrm{mg} / \mathrm{kgbw}$. The differences dose of the piroxicam and omeprazole based on the body weight of the rabbit.

Blood sampling in all three treatments was carried out by: test animals blood drawn from rabbit marginal veins as much as 1-2 ml with a span of 0 hours; 0.5 hour; 1 hour; 1.5 hours; 2 hours; 4 hours; 6 hours; 8 hours. The blood that has been taken is then put into a politube that has been given 2 drops of heparin, then vortex and centrifuged at a speed of $3000 \mathrm{rpm}$ for 10 minutes, then add $1 \mathrm{ml}$ of $20 \%$ TCA solution then centrifuged and taken supernatant. After that the levels were measured by using HPLC (High Performance Liquid Chromatography) by injecting $20 \mu 1$ [9].

\section{Result and Discussion}

Based on the plasma injection at 0.5 hours to 8 hours on an HPLC device, the concentration of plasma values obtained from the three treatments can be seen in Table 1. 
Tabel 1.Value of concentration of each treatment

\begin{tabular}{cccccccccc}
\hline Time & \multicolumn{3}{c}{ Treatment I } & \multicolumn{3}{c}{ Treatment II } & \multicolumn{3}{c}{ Treatment III } \\
\hline $\begin{array}{c}\text { Animal } \\
\text { test } \\
0.5\end{array}$ & I & II & III & I & II & III & I & II & II \\
1 & 0.5072 & 0.5077 & 0.5082 & 0.7241 & 0.7244 & 0.7252 & 0.7895 & 0.7897 & 0.7899 \\
1.5 & 0.9875 & 0.9877 & 0.9879 & 1.2925 & 1.2928 & 1.2930 & 1.5927 & 1.5930 & 1.5933 \\
2 & 1.2102 & 1.2105 & 1.2109 & 1.5119 & 1.5120 & 1.5124 & 1.6283 & 1.6285 & 1.6287 \\
4 & 0.9645 & 0.9647 & 0.9651 & 1.1781 & 1.1782 & 1.1787 & 1.3245 & 1.3248 & 1.3249 \\
6 & 0.6031 & 0.6033 & 0.6038 & 0.7434 & 0.7436 & 0.7440 & 0.9721 & 0.9724 & 0.9728 \\
8 & 0.2875 & 0.2877 & 0.2881 & 0.4363 & 0.4365 & 0.4367 & 0.6211 & 0.6215 & 0.6219 \\
\hline
\end{tabular}

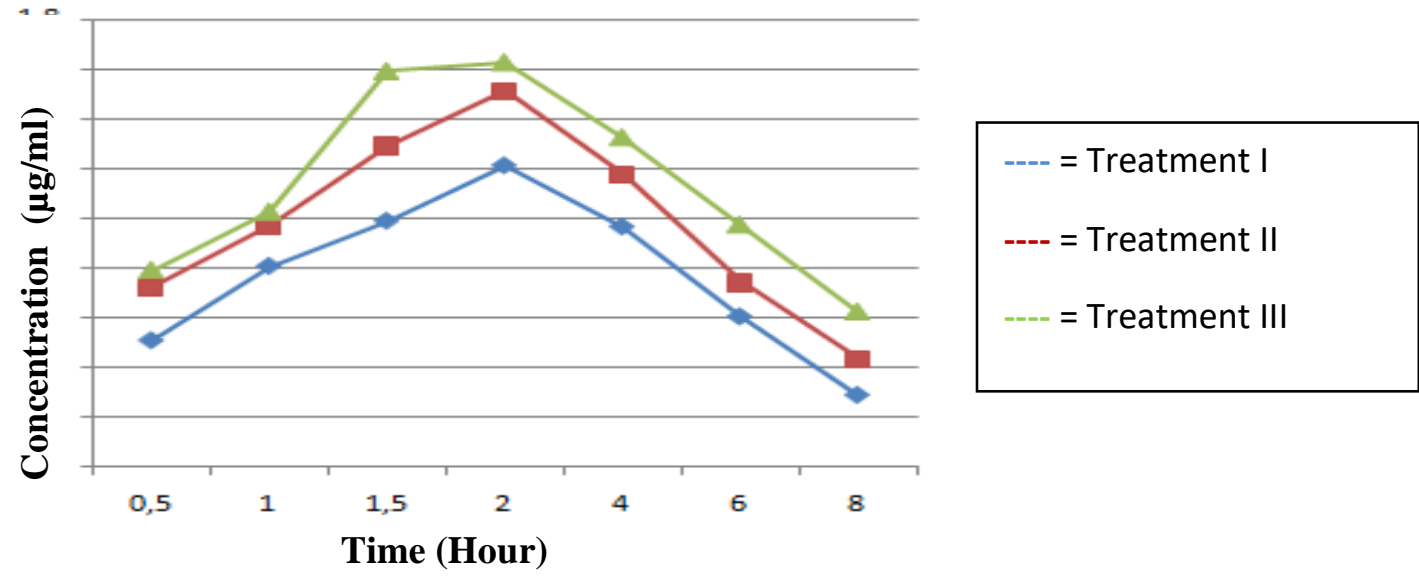

F'igure 1.Concentration Curves in Treatment I, II, III

From the results of the injection obtained levels from each treatment are then used to determine the value of the pharmacokinetic parameters. In the absorption rate or ka has increased from 1.7225 hours $^{-1}$ in treatment I to 2.77445 hours $^{-1}$ in treatment II and 3.0569 hours $^{-1}$ in treatment III. From the value of ka obtained there is a difference but it is not significant from the three test groups so that it shows that the value of the three treatments does not affect the value of the absorption rate, the Tmax value increased from 0.9408 hours in treatment I to 1.43 hours in treatment II and decreased 13249 hours in treatment III, the Cmax value increased from 1.2558 in treatment I 1.3603 in treatment II and 1.3901 in treatment III.

In the Mirakel study, it has been explained that the increase in the value of ka influences the

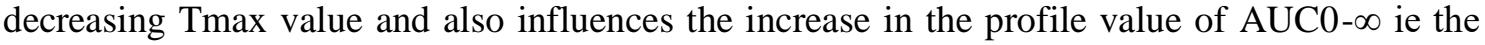
data from this study is $6.43985 \mu \mathrm{g} / \mathrm{L}$. Hours in treatment I to $8.1497 \mu \mathrm{g} / \mathrm{L}$ hours for treatment II and $9.0226 \mu \mathrm{g} / \mathrm{L}$ hours for treatment III. Factors that can affect the absorption profile are gastric emptying speed, $\mathrm{pH}$ of the absorption medium, fat-water partition coefficient and the phenomenon of first pass effect [10]. 
In the distribution profile, the three treatments did not show a significant change and also the effect on $\mathrm{Vd}$, namely the volume distribution value or $\mathrm{Vd}$ increased from $3.1349 \mathrm{~L}$ in treatment I to 3.7625 in treatment II and 3.7933 in treatment III. The AUMC0-nilai value which shows the

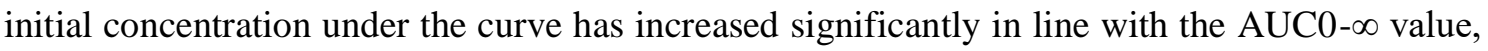
from 26,204 in treatment I to 36,2284 in treatment II and treatment III 38,0502. Factors that can affect the distribution profile values such as the bond between the drug and blood protein, the binding of the drug with tissue and partitions in fat and are not influenced by the administration of one or a combination of drugs so that the distribution profile value is not affected.

In the elimination profile obtained from the value of elimination speed or kel which decreased but not significantly from treatment I that is 0.5979 hours- 1 to 0.4883 hours- 1 in treatment II and then decreased to 0.4718 hours- 1 in treatment III and also in line with the $\mathrm{Cl}$ value of the three treatments which decreased from $1.8744 \mathrm{~L} / \mathrm{hr}$ in treatment I to $1.8375 \mathrm{~L} / \mathrm{hr}$ in treatment II and $1.7886 \mathrm{~L} / \mathrm{hr}$ in treatment III. $\mathrm{Cl}$ value describes the amount of drug that is cleansed and is a primary pharmacokinetic parameter so that physiological factors affect the change in value. It is seen that treatments II and III cause a decrease in $\mathrm{Cl}$ value which means there is a suspicion that the decrease in $\mathrm{Cl}$ occurs due to decreased metabolism by the liver and / or excretion by the kidneys. And the MRT value is the value that indicates the time the presence of drugs in the body has increased from 4.0690 in treatment I to 4.4453 in treatment II and decreased to 4.2172 in treatment III (Table 2). However, the three treatments showed no significant difference in value so it did not show the effect of the three treatments on drug elimination. From the data that has been obtained from each pharmacokinetic profile, there is no significant difference in the value of each treatment. So this shows that each treatment did not have a significant effect on the pharmacokinetic profile of the three treatments.

Table 2. Pharmacokinetic Parameter Values of the three Treatments

\begin{tabular}{|c|c|c|c|c|}
\hline NO & $\begin{array}{c}\text { Pharmacokinetic } \\
\text { Parameter }\end{array}$ & Treatment I & Treatment II & Treatment III \\
\hline 1 & $\mathrm{Ka}$ & 1.7225 & 2.7445 & 3.0569 \\
\hline 2 & Kel & 0.5979 & 0.4883 & 0.4718 \\
\hline 3 & $\mathrm{~T} 1 / 2$ & 1.159 & 1.419 & 1.4688 \\
\hline 4 & $\mathrm{Vd}$ & 3.1349 & 3.7625 & 3.7933 \\
\hline 5 & $\mathrm{Cl}$ & 1.8744 & 1.8375 & 1.7886 \\
\hline 6 & Tmax & 0.9408 & 1.43 & 1.3249 \\
\hline 7 & $\mathrm{Cmax}$ & 1.2558 & 1.3603 & 1.3901 \\
\hline 8 & AUC $0-\infty$ & 6.43985 & 8.1497 & 9.0226 \\
\hline 9 & AUMC $0-\infty$ & 26.204 & 36.2284 & 38.0502 \\
\hline 10 & MRT & 4.0690 & 4.4453 & 4.2172 \\
\hline
\end{tabular}

$\mathrm{T}$ count values obtained from concentrations of 10,14 and $18 \mathrm{ppm}$ respectively were 0.2239 , 0.3198 and 0.2562 (Table 3). After obtaining the calculated t value it will be compared with the $\mathrm{t}$ table value. The $\mathrm{t}$ table value uses $\alpha=0.05$, then $\alpha / 2=0.05 / 2=0.025$ and the value of $\mathrm{n}=$ 
3 , then $\mathrm{n}-1=3-1=2$. Then the value of $\mathrm{t}$ table is 4.30265 . The calculated $\mathrm{t}$ value obtained from each concentration is smaller than the $\mathrm{t}$ table value. Then it can be concluded that $\mathrm{H} 0$ is accepted or it can be said that the average compared is the same or there is no significant difference.

Table 3.T calculated values and $T$ tables

\begin{tabular}{ccc}
\hline Concentration & T Calculated & T Tables \\
\hline $10 \mathrm{ppm}$ & 0,2239 & \\
$14 \mathrm{ppm}$ & 0,3198 & 4,30265 \\
$18 \mathrm{ppm}$ & 0,2562 & \\
\hline
\end{tabular}

\section{Conclusion}

Based on the research that has been done, it can be concluded that the administration of omeprazole affects the inhibition of the enzyme metabolizing from piroxicam and also affects the pharmacokinetic parameters in the absorption phase and also excretion but not significantly. The piroxicam treatment group that was given 1 hour before omeprazole and the piroxicam treatment group was given together with omeprazole showed no significant effect on pharmacokinetic parameters.

\section{Acknowledgment}

The authors thanks to Faculty of Pharmacy, Institut Kesehatan Deli Husada Deli Tua for supporting this research.

\section{REFERENCES}

[1] Sumarno, "Interaksi Simetidin Terhadap Kinetika Eliminasi Parasetamol pada Kelinci,JurnalFarmasi Indonesia, vol.3, no.1, pp.9-12. 2006.

[2] B. D. Snyder, T. M. Polasek, and M. P. Doogue,"Drug Interactions Princeples and Practice," Australian Prescriber, vol. 35, no. 3, pp. 85-88, June. 2012.

[3] F. Rahmawati, R. Handayani, and V. Gosal, "Kajian Retrospektif Interaksi Obat di Rumah Sakit Pendidikan Dr. Sardjito Yogyakarta,"Majalah Farmasi Indonesia, vol. 17, no.4, pp. 177-183. 2006.

[4] M. Pirmohamed, S. James, S.Meakin, C. Green, A.K. Scott, T.J. Walley, et al," Adverse drug reactions as cause of admission to hospital: prospective analysis of 18820 patients," BMJ, vol. 329, pp 15-19. 2004.

[5] Aslam, M., Kaw Tan, C., and Prayitno, A.," Farmasi Klinis (Clinical Pharmacy) Menuju Pengobatan Rasional dan Penghargaan Pilihan Pasien," Jakarta: PT. Elex Media Komputindo. 2003.

[6] Forceia, MA.,et al.,"Geriatric Secrets, Third Edition," United States: Independence Square West. 2004.

[7] Hakim, L.,"Farmakokinetik Klinik,"Yogyakarta: Bursa Ilmu. 2012.

[8] Siswandono dan Soekardjo, B.," Kimia Medisinal Edisi 2," Surabaya: Airlangga University Press. 2000.

[9] Iersa, R., "Pengaruh Vitamin C pada Profil Farmakokinetika Natrium Diklofenak Terhadap Hewan Uji Kelinci,”M.S. Thesis Universitas Sumatera Utara. Medan. 2012.

[10] Mirakel Agatha Devi, "Pengaruh Pemberian Air Berkarbonasi Terhadap Profil Farmakokinetika Parasetamol Pada Tikus Putih Jantan," M.S. Thesis Universitas Sanata Dharma. Yogyakarta. 2007. 